scholars who are active in the international academic world had prepared the basic condition for the first international meeting for Old Testament studies. It is expected that this symposium should stimulate us to cultivate the germ of Old Testament studies in Japan. 
and colleagues from abroad.

I cannot enter here into details of important opinions expressed, and interesting discussions made, in the symposium. They will be published in the Symposium Volume, edited by Prof. M. Sekine and me, by the Ködansha Publishing Company by the end of 1981. As Prof. McCarthy has pointed out, "the quality of the papers was so high," that many of the participants were convinced that the Symposium Volume would be "a triangulation point for orientation in future research on the Davidic-Solomonic period" (quoted from a private communication of 31st December, 1979, from Prof. T.N.D. Mettinger of the University of Lund).

Finally, it seems important to mention again the fact that this was the first international meeting for Old Testament studies held in Japan. The reason that we had had no such meeting in our country before must be found not in the geographical distance between Japan and Europe, the Near East and America, but in the history that biblical studies had scarcely made good progress in our country until some little time ago. For Japan does not belong to the cultural area which has a Judeo-Christian heritage. We have only about a million Christians today, that is, less than one percent of the total population. Although the Japanese Christians have had a notable influence on the society considering their small numbers, it was not easy for us to develop biblical studies in the framework of this small community. However, with the general progress of scientific research in the field of humanities in Japan in recent years, we have made some progress also in biblical studies, in cooperation with scholars of ancient Near Eastern studies. Some of the results have been presented to the international academic world either in books, periodicals and abstracts published abroad or in the Annual of the Japanese Biblical Institute over the last five years. It is clear that the emergence of a group of Japanese Old Testament 
of personal letters from Prof. D.J. McCarthy, S.J., of the Pontifical Biblical Institute in Rome.

"Let me take the chance to thank you again for a splendid meeting. The more I look back on it, the more I am sure it was the best biblical discussion I have had the privilege to take part in. The quality of the papers was so high and the feeling of freedom to discuss and even disagree was remarkable. You assembled a fine group, which felt at home together. Considering the touchiness and clannishness so common among scholars, it was a remarkable achievement and I am proud and happy to have had a part as well as full of admiration for your Japanese group, who were not only the force which made us come together with such freedom but also, in your papers, showed a fine level of scholarship" (30th January, 1980).

"I found the symposium extraordinary. The group actually felt free and at ease with one another to the extent that we really discussed the papers, not just exchanged banalities, as is commonly the case at scientific biblical meetings. I think there were various reasons. One was the sensible limitation to the David-Solomon era. We all knew something about the field and so could talk together. Then, its being a meeting of established academic people helped...... But I emphasize, the main thing was the dedicated hospitality of you Japanese hosts from Prince Mikasa on down. The organization ran so smoothly, and you all seemed really to want us. It made use of a group, not just a set of strangers gathered in one place. The result for me was undoubtedly the best biblical meeting I have attended. The papers were interesting.... and the freedom of discussion made them doubly so as well as making the whole experience more profitable. One really learned. So thank you very much for a special meeting" (1st March, 1980).

I have found similar impressions about the symposium in all the letters which I received from both Japanese participants 
Trade in Horses and Chariots in its International Setting."

13) H. Tadmor (Hebrew University, Jerusalem): "Traditional Institutions and the Monarchy: Social and Political Tensions in the Time of David and Solomon."

14) J.A. Soggin (University of Rome): "Compulsory Labour under David and Solomon."

15) W.G. Dever (University of Arizona): "Monumental Architecture in Ancient Israel in the Period of the United Monarchy."

The themes of these papers are classified under four categories: a) the literary problems (nos. 1-4), b) royal ideology and religion (nos. 5-8), c) the political and economic problems (nos. 9-12) and d) the social structure (nos. 13-15). As this classification shows, the forum was planned with the intention of clarifying the characteristic features of the Davidic-Solomonic period from various aspects. As a result, all the papers read at the forum contributed to making valuable discussions centering around the common theme and complementing each other. This sort of mutual complement is not always attained in discussions at congresses. Owing to the nature of the theme, the problems dealt with in the forum were predominantly historical. Still, the forum successfully kept the balance in presentation of Old Testament studies by the inclusion of several papers about the literary problems and some researches on archaeological subjects. Since seventeen lecturers from eight countries gathered in the symposium, there were naturally not only differences of opinion but also those of scientific discipline and approach among the scholars. However, these differences did not prevent them from exchanging opinions but rather helped them to understand problems from different angles.

In order to convey a happy atmosphere among the participants produced by scientific achievements as well as by constructing colleagueship in the symposium, allow me to quote some parts 
University. The title of the former's lecture was "Ebla and the Old Testament," while the latter dealt with "Medicine in the Lands and Times of the Old Testament." The participants in the forum and the titles of their papers are as follows:

1) M. Sekine (Japanese Biblical Institute): "Lyric Literature in the Davidic-Solomonic Period - in the Light of the History of Israelite Literature."

2) R.N. Whybray (University of Hull): "Wisdom in the Reigns of David and Solomon."

3) K.K. Sacon (Tokyo Union Theological Seminary): "A Study of the Literary Structure of the Succession Narrative."

4) W.H. Schmidt (University of Marburg): "A Theologian of the Solomonic Era? A Plea for the Yahwist."

5) D.J. McCarthy (Pontifical Biblical Institute, Rome): "Social Compact and Sacral Kingship: Stimuli for Hebrew Covenant Thinking."

6) J.J.M. Roberts (Princeton Theological Seminary): "Zion in the Theology of the Davidic-Solomonic Empire."

7) T.N.D. Mettinger (University of Lund): "YHWH Sabaoth-The Heavenly King on the Cherubim Throne."

8) M. Tadmor (Israel Museum, Jerusalem): "Female Cult Figurines in Late Canaan and Early Israel: Archaeological Evidence."

9) T. Ishida (University of Tsukuba): "Solomon's Succession to the Throne of David-A Political Analysis."

10) A. Malamat (Hebrew University, Jerusalem): "A Political Look at the Kingdom of David and Solomon and its Relations with Egypt."

11) H. Donner (University of Tübingen): "The Interdependence of Internal Affairs and Foreign Policy during the DavidicSolomonic Period- with Special Regard to the Phoenician Coast."

12) Y. Ikeda (Hebrew University, Jerusalem): "Solomon's 


\section{欧文抄録 1 (国際聖書学シンポジウム報告)}

\section{The International Symposium for Biblical Studies, Tokyo, 5th-7th December, 1979}

Tomoo Ishida

The International Symposium for Biblical Studies, which was held at the International House in Roppongi, Tokyo, from the 5 th to 7 th of December, 1979, was the first international meet ing for Old Testament studies held in Japan. The symposium was organized by a special committee set up in the Society for Old Testament Studies in Japan (Nippon Kyüyaku Gakkai). Prof. M. Sekine, director of the Japanese Biblical Institute, assumed the chairmanship of the committee and Mr. Y. Onodera of the Middle Eastern Culture Center (Chūkintō Bunka Center) served as the secretary-general.

It was Prince Takahito Mikasa, honorary president of the Society for Near Eastern Studies in Japan (Nippon Orient Gakkai), who took the initiative for the realization of the symposium, and, in responding to Prince Mikasa's suggestion, Dr. Arthur M. Sackler, president of Medical Tribune International, New York, advised Mr. M. Yamagata, director of Medical Tribune Japan, to accept the sponsorship of the symposium. The financial support of Medical Tribune Japan enabled us to hold the three-day symposium by the participation of seventeen lecturers, including fourteen scholars from abroad.

The general theme of the symposium was "Archaeology and the Old Testament," which was discussed in two parts: two special lectures and a forum, in which fifteen papers concerning the problems of the Davidic-Solomonic period were read. The special lectures were given by Prof. D.N. Freedman of the University of Michigan and Prof. J.V. Kinnier Wilson of Cambridge 